\title{
Loyal to the Executive: The Effect of State Capacity on Local Horizontal Accountability
}

\author{
Martín Ordóñez
}

\begin{abstract}
The literature suggests that state capacity has a reinforcing effect on democracy. According to this literature, the capacity and usability of the bureaucracy that state capacity entails are essential for the provision of goods and services that help to consolidate and improve democratic regimes. This paper challenges this proposition. It focuses on local democracy and draws on the comparative method to describe and evaluate how bureaucratic capacity and usability can affect a critical component of democracy - the horizontal (or intrastate) oversight on the executive. Contrasting with the literature, this paper argues that, even in democratic regimes, state capacity can discourage accountability agents that are elected through popular vote. As the results show, bureaucracies that are well funded, highly professionalized, and usable give local executives an ample capacity to discourage accountability agents (municipal councils) from holding them accountable. Local bureaucracies with these characteristics can isolate municipal councils from local communities, strip them from autonomous constituent support, and render council members electorally dependent on the mayor. When local bureaucracies lack these characteristics, executives can still manage to influence horizontal accountability by exchanging council members' support for access to municipal resources they can distribute to increase their constituent support. Municipal councils' inclination towards accountability is, however, greater when local bureaucracies are highly capable but not usable. In this case, the local executive lacks influence on council members' relationship with local communities and, therefore, on municipal councils' disposition to hold them accountable.
\end{abstract}




\section{Introduction}

The literature suggests that democracy and state capacity are in a mutually reinforcing relation. On the one hand, based on the capacity and usability of the bureaucracy, state capacity is regarded as essential for the provision of services and goods that help to consolidate and improve democratic regimes. On the other hand, by bringing political peace, shaping national communities, and preventing the abuse of state resources, democracy can improve states' ability to carry on their functions. This mutually reinforcing relation would be broken only in the presence of undemocratic regimes (not the mere absence or the low quality of democracy), where the bureaucratic capacity and the usability of state administrations reinforce those types of regimes instead of promoting democracy.

Contrasting with this literature, this paper argues that, even in democratic regimes, state capacity can undermine a critical component of democracy — the horizontal oversight on the executive. It focuses on local democracy and draws on the comparative method to describe and evaluate how bureaucracies affect council members' inclination towards holding the local executive (i.e., the mayor and her administration). It observes four cases (municipalities) in Santiago de Chile, where council members and mayors are elected independently, and council members are formally mandated and in a privileged position to hold local executives accountable. Moreover, Chile provides a context of a sustainable state (The Fund for Peace 2019) and a consolidated democracy (The Fund for Peace 2019), where horizontal accountability is strong, corruption is comparatively low (Luna 2016; Rosales 2007; Transparency International 2012), and electoral democracy is also robust at the local level (Bland 2011). However, municipal councils in Chile have frequently shown a limited oversight over local executives (OECD 2017).

As the results show, bureaucracies that are well funded, highly professionalized, and usable give their mayors an ample capacity to discourage municipal councils from holding local executives 
accountable. Local bureaucracies with these characteristics can isolate council members from local communities, thus stripping them from autonomous constituent support, and rendering council members electorally dependent on the mayor. When local bureaucracies lack these characteristics, executives can still manage to influence horizontal accountability by exchanging council members' support for access to municipal resources they can distribute to increase their constituent support. Council members' inclination towards holding the local executive accountability is, however, greater when local bureaucracies are highly capable but not usable. In this case, the local executive lacks influence on council members' relationship with local communities and, therefore, on council members' disposition to hold them accountable.

\section{Bureaucracy and Democracy}

A growing body of literature suggests that democracy is in a positive and mutually reinforcing relationship with state and bureaucratic capacity. Some authors argue that a minimal level of state capacity is a necessary (although not sufficient) condition for democracy since it allows securing some basic requirements for its consolidation and development. Among these basic requirements, authors highlight the rule of law, maintenance of public order, tax collection, and the delivery of services in an orderly, predictable and legal manner (Suleiman 1999; Schumpeter 2008; Weber 2014; Linz and Stepan 1996; Fortin 2012; Fortin-Rittberger 2014; Bunce 2000; Fukuyama 2004; Hashim 2005; Przeworski 1995; Roberts et al. 1999; Huber, Rueschemeyer, and Stephens 1997; Kaufman et al. 1999; Tilly 2007; Wang et al. 1999; S. L. Mazzuca and Munck 2014). As Fortin (2012) highlighted, the positive impact of state capacity on democracy can also be seen in one critical component democracy: horizontal accountability, defined as the oversight and sanctions wield by independent agents of the state over the executive. As the author argues, the emergence and efficacy of oversight institutions depend on the existence of an effective, honest, and well-funded bureaucracy. 
However, other authors argue that democracy can also contribute to the development of state and bureaucratic capacity. In particular, they propose that democracy can bring the political peace that allows states to develop, help to shape the national communities corresponding to specific states, and some of its characteristics—-such as the presence of competition, veto players and open civil societies_can help to prevent the abuse of state resources (Fortin 2012; Bäck and Hadenius 20o8; Grzymała-Busse 2007; Weingast and Moran 1983; Keefer and Stasavage 1999; S. L. Mazzuca and Munck 2014).

The arguments suggesting a positive and mutually reinforcing relationship between state capacity and democracy usually rely on Weber's distinction between patrimonial and bureaucratic administrations. According to this distinction, patrimonial administrations lack a separation between private and official spheres, and therefore, the public office tends to be arbitrarily administrated. Bureaucratic administrations, on the other hand, privilege an impersonal and rationalized management of public office, thus characterized by rule-oriented government, predictability, and meritocracy (S. Mazzuca 2012; Bellin 2004; Bendix 1998, 418-22). According to the literature, the bureaucratic character of public administrations is essential for states to support democracy, since it allows the successful provision of basic public goods and enforcement of citizen rights (Mazzuca 2012, Suleiman 1999, Linz and Stepan 1996), the strengthening of democratic states' legitimacy (Suleiman 1999; Kochanowicz 1994) and the bureaucratic tolerance of democratic transitions (Bellin 2004).

Linz and Stepan (1996) add another characteristic to Weberian bureaucratic administrations as a condition for the positive influence of bureaucracies on democratization. These bureaucracies must be usable, meaning that bureaucrat must be willing to cooperate with the current government in their attempts to govern effectively ${ }^{1}$. According to these authors, unusable bureaucracies may result

\footnotetext{
${ }^{1}$ Linz and Stepan (1996) do not offer an explicit definition of the usability of bureaucracies. Moreover, they
} 
in states' failure to provide the goods and services that strengthen and legitimize a democratic regime.

With usability, then, Linz and Stepan allow bridging between this literature and authors suggesting that state and bureaucratic capacity can also help to prevent the democratization of nondemocratic regimes (Way 2005; Bäck and Hadenius 2008; Levitsky and Way 2010; S. L. Mazzuca and Munck 2014; Albertus and Menaldo 2012; Bellin 2004). Using different concepts—such as control (Bäck and Hadenius 2008; Way 2005), will (Bellin 2004), or cohesion (Levitsky and Way 2010) - authors have argued that the probability with which bureaucrats will follow the orders of their superiors is a critical factor explaining why highly capable administrations can be a useful tool for autocrats seeking to prevent democratization. When this probability is high, these administrations can help them by either increasing their legitimacy through efficient service delivery or to repressing the attempts to democratize. Analogously, Linz and Stepan suggest that, to help to consolidate democracy, an effective bureaucracy must be willing to be similarly useful to the (newly) democratic government, thus rejecting the idea that bureaucracies have an automatic impact on democratization. As Bäck and Hadenius (2008) argued, then, administrations that are usable and capable reinforce the current type of regime, while unusable and incapable ones tend to fall in an intermediate position between democracy and autocracy.

Contrasting with this literature, this paper argues that, even in a democratic regime, bureaucratic administrations that are both capable and usable can harm a critical dimension of democracyhorizontal accountability. As the cases analyzed show, these bureaucracies can discourage agents of horizontal accountability, especially when they are a separately elected branch of government

use it indistinctly to refer to bureaucracies' availability to current governments, civil society, and the opposition. However, they are explicit, first, in differentiating usability from "a functioning state" and, therefore, from state capacity. Second, in portraying usability as something that is hampered by bureaucrats who remain staunchly loyal to the previous administrations (in the cases they analyzed, loyal to previous authoritarian or totalitarian regimes, right after democratization). 
and, therefore, their ability to perform their accountability duties depend on the support they receive from their constituencies (Moreno, Crisp, and Shugart 2003; Wirls 2015). Highly capable and usable bureaucracies can isolate accountability agents, rendering them irrelevant for decisionmaking processes, and making them dependent on the executive branch to obtain constituent support. This situation, then, leaves, these two branches in an informal hierarchical relation that discourage accountability, as Moreno et al. (2003) argue. This hierarchical relation, however, disappears when bureaucracies are capable but not usable. In these cases, the executive branch, despite its technical capabilities, becomes inefficient and loses its influence on accountability agents' constituent support. These agents, then, are electorally independent from the executive branch and can hold them accountable without risking their constituent support. Finally, when these bureaucracies take the form of low-capacity patrimonial administration, the executive can still manage to influence horizontal accountability. The executive can, in particular, exchange accountability agents' loyalty (and disregard for their accountability issues) for access to resources they can distribute to increase their constituent support.

\section{Local Horizontal Accountability}

This paper analyzes horizontal accountability—the oversight and sanctions wield by independent agents of the state over the executive-conceiving it as a critical determinant of the quality of democracy. Researches and reports have found patterns of democratic elections combined with arbitrary and particularistic behavior of rulers, which include violation of human rights, abuse of authority, corruption, improper use of public resources and impunity for state actors (Diamond and Morlino 2004; Mainwaring 2003; Schedler, Diamond, and Plattner 1999; Zakaria 1997). This combination of democratic procedures to select rulers, on the one hand, and rulers' undemocratic behavior once in office, on the other hand, has prompted the distinction between liberal 
democracies and illiberal (Zakaria 1997) or delegative (O’Donnell 1994) democracies. While liberal democracies are characterized by the respect for civil rights and the restrain of state power, in illiberal or delegative democracies "whoever wins election to the presidency is thereby entitled to govern as he or she sees fit," without much more constraints than the term limits of office (O'Donnell 1994, 59). This distinction between types of democracy has a direct translation into degree or quality of democracy, with liberal democracy implying more or better democracy (Marshall and Gurr 2014; Diamond and Morlino 2004).

In this context, the literature regards horizontal accountability as critical for improving democracy. In particular, authors highlight horizontal accountability's capacity to prevent the arbitrary use of power that characterize illiberal and delegative democracies by reducing levels of corruption, the impunity of state actors, and the improper use of resources. Thus, horizontal accountability is expected to improve the legitimacy and quality of democracy and promote the transition towards a more liberal or better democracy (Schedler, Diamond, and Plattner 1999; Mainwaring and Welna 2003; O’Donell 1994; Diamond and Morlino 2004).

Analyzing horizontal accountability at the local level in Latin America is of particular relevance. In the context of the transitions out from dictatorship, decentralization has promised to play a critical democratizing role, primarily due to the deconcentration of power that it implies (Montero, Samuels, and Helen Kellogg Institute for International Studies 2004; Devas and Delay 2006; Bland 2011). Consistently, decentralization has aimed at restoring elected local governments, redistributing authority, overcoming exclusionary and undemocratic social structures, and improving the efficiency of the delivery of services (Devas and Delay 2006; Bland 2011; Nickson 2011). However, decentralization alone has been unable to deliver these democratizing outcomes and has resulted, instead, in the development and maintenance of subnational undemocratic practices, combined with recurrent democratic elections (Giraudy 2013; Behrend and Whitehead 2016; 
Behrend 2011; Cornelius, Eisenstadt, and Hindley 1999; Herrmann 2010; Gervasoni 2010; Gibson 2005). These practices, then, replicate the illiberal democratic pattern observed at the national level. The study of these subnational undemocratic regimes has been mostly concentrated at the state level (Pino 2017), while the research on local democracy has focused on the relationship between citizens and local governments-either under its electoral ${ }^{2}$ or citizen direct participation ${ }^{3}$ dimensions. Thus, the literature has paid little attention to the democratic relevance of horizontal relations between equally elected local authorities. However, frequent reports of democratically elected mayors holding undemocratic practices ${ }^{4}$ suggest that local governments should be similarly affected by these situations.

\section{Case Selection}

Four cases (municipalities) from Santiago de Chile were selected for this research. Like most countries in Latin America, Chile's local governments have followed, since 2004, ${ }^{5}$ a Strong Mayor model, which separates the local executive body from the local legislative body (both of which are elected through popular vote). Both mayors and council members are elected every four years and can be reelected indefinitely. The election of council members follows an Open-List Proportional Representation, and the size of municipal councils can vary between six to ten members, depending on the size of the respective community population (Ley $N^{0} 18.695$, Orgánica Constitucional de Municipalidades 2006).

\footnotetext{
${ }^{2}$ See, for example, Bland (2011).

${ }^{3}$ Following the successful experience of Porto Alegre, the use and implications of local participatory mechanisms in the region have been profusely studied. See, for example Baiocchi (2005), Wampler \& Avritzer (2004), and Montambeault (2016).

${ }^{4}$ See, for example, Barozet (2004), Eaton \& Prieto (2017), Arévalo León (2015), and Silva (2016).

${ }^{5}$ Between 1992 and 2004, only the members of the municipal council were elected through popular vote. Mayors were elected by the Municipal Councils, choosing them from among council members, and usually corresponding to the candidate with the highest number of votes.
} 
According to the literature, by separating local executives and legislatures, the Strong Mayor model leaves the latter in a privileged position to oversee the former (Lankina 2008; Sisk 2001; Bowman and Kearney 2011; Devas and Delay 2006; Nickson 2011; Rosales 2007; Ley $N^{0}$ 18.695, Orgánica Constitucional de Municipalidades 2006). Moreover, local councils in Chile are formally mandated to oversee local executives and are endowed with formal attributions for that duty. Local councils can, for example, summon any head of municipal departments for interrogation, and any council member can request information through the mayor, who is required to provide a written answer within a limited time. Council members also receive the advice and assistance of the Control Unit $^{6}$ of the corresponding municipality and can request an external audit to assess the financial status, the implementation of the budget, and the implementation of the Municipal Development Plan. Although the law does not provide council members any formal provision for sanctioning mayors or their administrations, they can sanction mayors indirectly by submitting complaints to state agents with direct sanctioning power-the criminal justice system, the Comptroller General's Office and the Electoral Courts (Rosales 2007; Ley $N^{\circ}$ 18.695, Orgánica Constitucional de Municipalidades 2006).

Mayors, however, remain preponderant figures in local politics. As the highest authority in a municipal government, they have a high degree of control over local decision making and de facto control over the appointment and career development of municipal bureaucrats. Although municipal councils participate in municipal decision-making, their influence on these decisions is limited, since it is up to the mayor to set the agenda for issues to be voted upon, and the council cannot make changes to the budget presented by the mayor. Moreover, the status and resources of municipal councils_characterized by low pay, part-time hours, and lack of formal resources and

\footnotetext{
${ }^{6}$ The Control Unit is an autonomous department of the municipal administration, which works with the technical assistance of the Comptroller General's Office to oversee the legality of the municipalities' actions (Rosales 2007; Ley $N^{0}$ 18.695, Orgánica Constitucional de Municipalidades 2006).
} 
staff to carry out their duties-are in sharp contrast with those of mayors, who have a full-time schedule and salary, and exercise wide control over the municipal bureaucracy (Rosales 2007; Ley $N^{0}$ 18.695, Orgánica Constitucional de Municipalidades 2006; Rivera-Ottenberg 2004).

Chilean local governments remain independent from national politics to a great degree, despite their strong dependence on the national state ${ }^{7}$ and their heavily managerial set-up-limiting the scope of their attributions and functions, and emphasizing administration over self-government (Nickson 2011; OECD 2017; Fernández Richard 2013). In particular, national parties have scant relevance in local politics, where parties are unable to oppose the nomination of incumbent candidates and party elites usually leave local politicians unchecked (Rosales 2007; Luna and Altman 2011). ${ }^{8}$

Within Chile, the selection of cases (municipalities) was restricted to the metropolitan area of Santiago. Santiago is divided into 34 administrative units (comunas), each of them managed by a municipality (Ducci 2002). In socioeconomic terms, Santiago's comunas are highly heterogeneous

\footnotetext{
${ }^{7}$ Municipalities receive a significant proportion of their funds (above $50 \%$ on average) from the national government, and they share with the central state the responsibility for many of these functions. For example, the Law regulating Chilean municipalities distinguishes two types of functions they are required to carry out-those that are the exclusive responsibility of the corresponding municipality, and those for which municipalities are allowed to share the responsibility with other state agencies.

Under the exclusive responsibility of the municipality, the law mentions: the elaboration of the Communal Development Plan (Plan de Desarrollo Comunal) and the Regulatory Plan (Plan Regulador); the promotion of community development; Implementation and enforcement of the laws on transportation and public transit; Implementation and enforcement of the laws on construction and urbanization; and the maintenance and beautification of the commune.

Under shared responsibility with other state agencies, the law mentions: education and culture; public health and environmental protection; the provision of social and legal aid; job training, and the promotion of employment and production; tourism, sports and recreation; urban development and road management; building of social housing and water and sewage infrastructure; public transit and transportation; risk prevention and assistance in case of emergencies or catastrophes; social prevention, and implementation of public security measures; promotion of equal opportunities between men and women; and the development of local activities of common interest (Ley $N^{0}$ 18.695, Orgánica Constitucional de Municipalidades 2006).

8 This low relevance of political parties at the local level was also reported by council members and parliamentarians interviewed for this research, who highlighted the lack of accounting and control mechanisms over council members, while el que tiene mantiene (the one who has it, keeps it) was reported as the general rule of thumb for nominating incumbent candidates.
} 
when compared to each other, although highly internally homogeneous (Sabatini, Cáceres, and Cerda 2001). Therefore, Santiago provides a universe of possible cases that are highly diverse on a critical dimension, while allowing for control of the effects of contextual and institutional variables.

The case selection followed a diverse case strategy, which focused on maximizing the variance of the dependent variable (Seawright and Gerring 2008). However, due to the lack of available information on each local council's disposition for horizontal accountability, the case selection maximized the variance of critical contextual variables considered as proxies for the dependent variable. These variables include, first, the municipalities' levels of party competition, according to the margin of victory in former elections of councils and mayors, and the party composition of the council. Second, the political coalition dominating the local government was considered, according to the party membership of mayors. Finally, the socioeconomic level of the corresponding population was taken into account, according to the rate of poverty, the average years of schooling, and the average per capita income of these comunas. ${ }^{9}$ Thus, the municipalities selected were Estación Central, Quinta Normal, Providencia, and Las Condes. Table 1 summarizes the distribution of these characteristics across the municipalities selected for the research. These cases were analyzed considering the term between the elections of December 6, 2012, and December 6, 2016.

\section{Variables and Analysis}

The paper takes as the dependent variable, the local councils' disposition to hold mayors accountable-rather than their capacity to do so or actual instances of accountability. This disposition is understood here as the local councils' (and council members') willingness to act, thus

\footnotetext{
${ }^{9}$ As the following sections show, this selection strategy obtained cases with different values on the dependent variable, although these values were not correlated with any of the variables used to select cases.
} 
highlighting their willingness as an intrinsic and latent characteristic, which can materialize into concrete actions when specific conditions are met (e.g., when the mayor incurs in illegal behavior). This disposition is a fundamental element for the final results of horizontal accountability. On the one hand, without a minimum willingness to act, the variation on the local councils' capacity for horizontal accountability-manifested in their powers and organization-is inconsequential. On the other hand, this disposition highlights the element of potentiality that is essential for horizontal accountability and makes its assessment independent of actors' good or bad behavior (Mulgan 2000; O’Donnell 2003). ${ }^{10}$

This variable was measured considering three sources of information-semi-structured interviews with critical actors, printed and electronic news media reports issued during the period analyzed, and council members' reports to the Comptroller General's Office against the local executive." The interviews with critical actors were conducted in 2015 and 2016. These actors include council members, municipal bureaucrats, leaders of neighborhood associations (Juntas de Vecinos), and congresspersons representing these municipalities. All council members and congresspersons were contacted, and those willing to participate in the research were interviewed. The selection of municipal bureaucrats and leaders of neighborhood associations followed a snowball sampling method, starting from the suggestions made by the council members interviewed, and using a saturation of information criterion. Table 2 shows the number of interviews implemented in each case. In total, 78 interviews were implemented. Table 3 specifies the number of news reports and

\footnotetext{
${ }^{10}$ As Mulgan (2000) argued, it is "the ever-present threat of being called to account" (p. 567) that ultimately allows keeping state agents under control. Similarly, O’Donnell (2003) argued that would-be transgressors assess the probability of being caught and sanctioned before committing the transgressions, and it is because of these assessments that horizontal accountability can effectively deter transgressions. Moreover, because of these characteristics and effects, it is also possible to judge the efficacy of horizontal accountability, even when only a few transgressions are committed (O'Donnell 2003).

${ }^{11}$ The research also considered reports made by council members to the corresponding Electoral Tribunals and the Prosecutor General's Office. However, no complaints were filed with the Electoral Tribunals, while the Prosecutor General was not allowed to provide identifying information about the individuals who submitted the reports.
} 
council members' reports to the Comptroller General's Office analyzed for each case.

The dependent variable was measured starting with the aggregated assessment of council members' individual disposition, which was then complemented with the perceptions about Municipal Councils as a whole. This strategy allowed for the incorporation not only of the individual disposition of council members but also of the Municipal Councils' willingness to carry out mechanisms of accountability that require the participation of a majority (e.g., providing quorums for interrogating municipal bureaucrats in the council's sessions). Council members were individually categorized as either loyal, skeptic, or ambivalent to their mayor, thus revealing their disposition to hold them accountable. This categorization was primarily made following the predominant perceptions reported in the interviews and corroborated with council members' appearances in news media and their reports to the Comptroller General's Office. Consistently, loyal council members did not report the local executive to the Comptroller General's Office and did not appear criticizing the mayor in the news. Skeptic council members either reported the local executive to the Comptroller General's Office or appeared in the news predominantly criticizing the mayor. Ambivalent council members, in general, did not report the local executive to the Comptroller General's Office and either appeared in the news indistinctly supporting and criticizing the mayor or appeared in the news no more than once.

The municipal councils' disposition to hold the mayor accountable was categorized as either Low, Medium, or High, considering the perceptions reported in the interviews and the proportion of loyal, skeptic, and ambivalent council members. They were categorized as Low if the sources reported a generalized loyalty to the mayor, and at least two-thirds of the council members were identified as loyal (Las Condes). They were categorized as Medium if at least one-third of council members showed an ambivalent disposition to hold the mayor accountable (Estación Central), or the skeptic council members were one member below the half of the council (Quinta Normal). It 
was categorized as High if the majority of council members showed a high disposition to hold the mayor accountable (Providencia).

The effect of bureaucracies on the dependent variable was investigated adapting Wirls's (2015) institutional power model, which allows analyzing the influence of one state agent over another and the policy outcomes of the system within which it operates. According to the author, this influence depends primarily on the three constitutive components of state agents. First, their powers, understood as their constitutional authority, the duties delimiting their functions, and the formal tools they are provided with for these purposes (e.g., the power to veto, appoint or impeach). Second, their organization, encompassing institutional structure (including size, membership, tenure, and remuneration), procedures (their rules of operation and decision-making), and other internal resources (such as staff). Finally, their constituency, understood as the sympathy and support of public opinion or relevant segments of society. These three components interact (organizational capacity and constituent support, for example, are necessary to use powers effectively and legitimately), and other state agents can affect their availability, using their own powers, organization, and constituency to obtain that effect.

Under this framework, horizontal accountability can be understood as tools that are either legally granted or not legally prohibited (powers) to a state agent, who can use them to influence other state agents and the policy outcomes of the system. By doing so and considering state agents' accountability attributions in connection with their organization and constituency, this framework provides a way to systematically analyze how and when they can and are willing to make effective use of their legal accountability attributions. Also, this framework provides a way to analyze how other state agents (such as the bureaucracy) can affect accountability agents' ability (i.e., capacity and willingness) for horizontal accountability. Since this ability dependent on the interaction of 
their three constitutive institutional components (powers, organization, and constituency), other agents can influence it by affecting these components. Moreover, since each agent's influence is also dependent on these components, it indicates the resources and motivation they have to influence another agent's ability for horizontal accountability.

Consistently with this framework, the effect of the bureaucracy on the dependent variable was investigated considering three paired relationships: council members and local communities; council members and local executives; and local communities and local executives. These relationships were investigated primarily through semi-structured interviews with critical actors in 2015 and 2016 (see Table 2). The dimensions analyzed in each paired relationship were determined inductively, including the components that the interviews revealed as significant for this paper. Table 4 shows the dimensions that were considered in the council members-local communities.

Consistent with the local executives' formal orientation towards serving local communities, the elements analyzed in the relationship between local executives and communities include the executives' delivery of public goods and services and their role in promoting community associations. These elements are organized according to the three dimensions of the executive organization component (see Table 4). Here, although the term capacity appears explicitly mentioned in the third dimension only, state capacity ${ }^{12}$ was considered as an essential element of all of them, consistent with the capabilities that that Soifer (2008) identifies in his analysis of infrastructural power. ${ }^{13}$ However, these components address only one of the components of state capacity considered by Saylor (2014) —its ability to provide public goods and services, leaving aside the institutional dimension, relative to the creation of rules that shape human interaction. The local

\footnotetext{
${ }^{12}$ Considering State Capacity as the "ability of government officials to actually penetrate civil society, and to implement logistically political decisions" (Mann 1984, 189).

${ }^{13}$ As Saylor $(2014,2)$ reminds us, Mann's definition of infrastructural power quoted here is what scholars more commonly call state capacity.
} 
relationship between executives and communities was investigated by resorting to interviews with critical actors, and public information that was available in Chile’s Sistema Nacional de Información Municipal (SINIM), ${ }^{14}$ the CASEN 2015 survey, ${ }^{15}$ and Chile's Ministerio de Hacienda (The Ministry of Finance).

\section{Local Councils' Disposition for Horizontal Accountability}

As Table 5 shows, the cases analyzed vary in terms of council members' disposition to hold mayors accountable. The Municipal Council of Las Condes showed the lowest levels in these regards. The majority of its members (six out of nine) were recognized as unfalteringly loyal to the mayor and the council as a whole was frequently described as "very collaborative with the mayor," where "in the end, everyone supports [him]" (Loyal UDI Council Member 2, Las Condes), even the most skeptical of its members "who sometimes can really disagree with something, but end up voting as the mayor asks" (Ambivalent RN Council Member 2, Las Condes). Only three council members showed a more questioning stance, and only one of them (the single council member from an opposition party) was recognized as decidedly skeptical about the mayor and his administration. Consistently, this skeptical council member is the only one appearing often in the national news media, either criticizing or opposing the mayor or his administration. In one of these appearances, for example, the mayor singled him out as the opposition to his administration. Another example describes a public argument between the mayor and the skeptical council member, where the mayor refused to implement an administrative investigation for the misconduct of municipal bureaucrats requested by the skeptical council member.

\footnotetext{
${ }^{14}$ National System of Municipal Information.

${ }^{15}$ The CASEN survey is implemented periodically by Chile's Ministry of Social Development. It collects information to produce a socioeconomic breakdown of the population. In its 2015 version, it was representative at the commune level for 23 communes of Santiago.
} 
The Municipal Councils of Estación Central and Quinta Normal presented a moderate disposition to hold their mayors accountable. In Estación Central, over one-third of the council members (3) were identified as holding an ambivalent stance towards the mayor. The first of them was from the mayor's party, who was described as "independent" (Skeptic PS Council Member, Estación Central) or "unruly, [usually] criticizing the administration" (Loyal UDI Council Member 1, Estación Central), and who admitted having a distant relationship with the mayor and being "not willing to be [the mayor's] useful fool" (Ambivalent UDI Council Member, Estación Central)— although he usually backs him, supporting him in critical roll-call votes in the council. The other two ambivalent council members came from opposition parties, one of them, the Ambivalent PS who "used to support the mayor, but [...] she switched sides", while the Ambivalent PDC "sometimes supports the opposition and sometimes supports the mayor-most of the time he supports the mayor" (Skeptic PS Council Member, Estación Central). The two skeptical council members came from opposition parties. They were consistently identified as highly critical of the mayor, and in most of their appearances in the news media, they criticized the mayor or his administration. On one occasion, one of them also reported the mayor to the Comptroller General's Office. Three council members were identified in the interviews as loyal to the mayor. Surprisingly, among them was a council member from an opposition party, who was described to be "like he was from the UDI—he [...] votes for everything in favor of the mayor" (Skeptic PS Council Member, Estación Central), while, in an interview, he openly defended the mayor and his administration and criticized the council members who opposed the mayor.

In Quinta Normal, council members were clearly divided between the loyal members and those who were skeptical of the mayor, where the second group was one council member below the half of the council (three out of eight). Notably, these groups cut across partisan divisions. Two 
members of opposition parties were identified as loyal, usually described as "personally close to the mayor" (Loyal PDC Council Member 2, Quinta Normal), who have too easily "approved all [the mayor's] projects," and who, along with the other loyal council members, shielded the mayor against other council members' attempts to hold her accountable-e.g., by not providing the quorum necessary for the session (Skeptic PS Council Member, Quinta Normal). Similarly, two members of the mayor's coalition were identified as skeptical of the mayor, while, in their interviews, they openly criticized the mayor and her administration. Consistently, one of them reported the mayor and her administration to the Comptroller General's Office on four occasions, and the other one concentrates all the appearances of council members in the news media, manifesting, in all of them, either a skeptical or an ambivalent stance towards the mayor.

Finally, in Providencia, a majority of council members showed a strong disposition to hold their mayors accountable (five out of eight). Here, the stark division between allies and skeptics of the mayor overlapped almost perfectly with the corresponding party divisions in the Municipal Council, with the council members from the mayor's coalition remaining loyal to her and the ones from opposition parties holding a skeptical stance. The only exception-tilting the balance towards the skeptics-was a council member from the mayor's coalition who, after a personal conflict with the mayor at the beginning of the term, joined the opposition council members. Thus, he was reported to "vote on many things in accordance with [the opposition]," "work with [them] to remove the mayor from office" (Loyal PS Council Member, Providencia), and left "many projects in a difficult position" for their approval (Loyal PDC Council Member, Providencia). He also appeared in the news media criticizing the mayor and joined the skeptical council members to present one [complaint/report] against the mayor to the Comptroller General's Office. 
As Table 6 shows, these councils' disposition for horizontal accountably varies across the socioeconomic status of the corresponding populations and their party competition levels. These results contradict explanations based on the pressure of constituencies on their representatives to hold other authorities accountable (which are expected to be higher among people of higher socioeconomic status), ${ }^{16}$ and explanations expecting higher horizontal accountability as a result of higher party competition or the mere presence of opposition parties. ${ }^{17}$ Consistent with the literature (Lawson and Rakner 2005; Bowman and Kearney 2011; Hiskey and Seligson 2003), the simple variation in the disposition for horizontal accountability also challenges explanations based on the council members' formal attributions, since these attributions are constant across these cases. The party membership of the mayor may offer a more promising explanation since, in the cases analyzed, the council members from the right showed higher loyalty to mayors from their parties. However, this explanation still leaves important questions unanswered. First, as Table 5 shows, some council members from these mayors' coalitions were not strictly loyal to them and held, instead, an ambivalent stance. Second, this explanation does not explain why some council members from the right remained loyal or ambivalent toward mayors from the left. Finally, it is not evident why right-leaning council members should be more loyal to their mayors and, therefore, the mechanism linking loyalty and party membership would still need to be elucidated. As the following sections argue, local executives' capacity to influence council members' disposition for horizontal accountability provides a more promising explanation for these results.

\footnotetext{
${ }^{16}$ See, for example, Lankina (2008), 8/30/20 9:10:0o PMBardhan and Mookherjee (200o), Agrawal and Gupta (2005), Ahmad et al. (2005), Dixit and Londregan (1996), Calvo \& Murillo (2004), Kitschelt and Wilkinson (2007), and Schaffer and Desposato (2007).

${ }^{17}$ See, for example, Packel (2008), Crook (1999), and Blair (2000).
} 


\section{Capable Bureaucracies and Isolated Council Members}

As the results show, local executives can influence council members' disposition for horizontal accountability based on these executives' organizational features-their usability and capacity to address local communities' demands, the internal procedural rules regulating bureaucrats' interactions with council members, and the resources and opportunities to interact with local communities that they can distribute among council members.

As the case of Las Condes illustrates, municipal bureaucracies with a high capacity and usability to address local communities' demands have an organizational advantage over local councils in their efforts to obtain local constituents' support. This advantage ultimately translates into council members' isolation from local communities and their subsequent need to rely on the help of the executive to increase their constituent support.

Las Condes' municipal bureaucracy was characterized by its abundant availability of resources (see Table 7), its active involvement in local communities, and its high capacity and loyalty when receiving and responding to local demands. Two factors made this bureaucracy's involvement in local communities remarkable. First, the unusually plentiful resources it dedicated to finance local organizations and their activities (see Table 8). Second, the transformation of neighborhood associations ${ }^{18}$ into critical partners of the municipal bureaucracy by transferring to them some of the duties associated with local community relations. Neighborhood associations, for example, were made responsible for connecting neighbors with the bureaucrats who could address their demands-thus, "every [request from the neighbors] is first made to the neighborhood

\footnotetext{
${ }^{18}$ Neighborhood Associations (Juntas de Vecinos) are civil society organizations representing the people who live in the same Unidad Vecinal - a territorial subdivision of a commune. Their formal purpose is to promote the development of the community, defend the interests and rights of their members, and collaborate with authorities of the state and municipalities (Ley $N^{\circ} 19.418$, Sobre Juntas de Vecinos Demás Organizaciones Comunitarias 1997). They were formally recognized in 1968, represent about one-third of all civil society organizations in the country, and are highlighted by their role in promoting community life and holding a dialogue between these communities and the authorities (Delamaza 2018).
} 
association, and these associations made the requests [to the municipality]" (Local Leader 2, Las Condes)—and for providing some municipal services to neighbors (e.g., workshops, local tournaments, and community libraries). These organizations, therefore, worked as an extension of the municipality, similar to the administrative grassroots engagement system described by Read (2012), ${ }^{19}$ and that was unseen in the other cases analyzed.

During the period analyzed, Las Condes also presented a comparatively large and professionalized bureaucracy (See Tables 9 and 10), which was frequently described as highly loyal to the mayor. In particular, the high-rank positions were "filled with bureaucrats of unyielding loyalty," and there were strong measures to ensure "bureaucrats' commitment [and] accountability to their hierarchy-the ones who fail to account for their job are fired very soon [or are] severely affected in their pay” (Ambivalent RN Council Member 2, Las Condes).

These characteristics of the bureaucracy added to the ample availability of resources, were translated into an attentive responsiveness to communities' demands. As the interviews reported, they were able to address a wide range of demands, including education, housing, security, health care, field trips, and sporting events. As one council member mentioned, "we cover everything [...], we don't lack anything [...]. Here, you can't say to someone 'look, come back in two months and then your problem will be solved"' (Ambivalent RN Council Member 2, Las Condes). Complementing this perception, a local leader closer to the opposition to the mayor expressed, "we get [all our projects] financed [...]. They have helped me with everything I have requested" (Local Leader 2, Las Condes).

The Municipal bureaucracy's skillful capacity to address community demands had two

\footnotetext{
${ }^{19}$ According to the author, administrative grassroots engagement is a system in which "states create, sponsor, and manage networks of organizations at the most local of levels that facilitate governance and policing by building personal relationships with members of society". Among other relevant characteristics, in these systems, local leaders serve as a connection between neighbors and state agents; the local organizations lend assistance to run a variety of state programs; and they provide various community-oriented services (Read 2012, 3-4).
} 
significant consequences for the council members' disposition to hold the mayor accountable. First, it increased the mayors' popularity and his electoral influence on local communities. Second, it added to municipal rules prohibiting council members from bringing local demands directly to municipal bureaucrats, and it contributed to council members' isolation from local communities and their electoral dependence on the mayor. As council members described, due to the high level of responsiveness of the municipality, local community organizations were "heavily encapsulated by the municipality" and, therefore, they "will never bring a complaint to you, even if you are a council member from the opposition" (Skeptic PDC Council Member, Las Condes). In Las Condes, "everything is structured by the bureaucracy so that all the demands [can be] resolved without passing through the council members." Council members were, therefore, described as "invisible" and "nonexistent" for local communities (Ambivalent RN Council Member 2, Las Condes).

Council members' invisibility made them highly electorally dependent on the mayor and, therefore, unable to oppose him and hold him accountable, even if they disagreed with his propositions. As one of them explained, "Stupid ideas are approved [because council members] like to be on good terms with [the mayor] — who is ultimately the one who decides [...]. He is very popular in the commune, so council members like to be seen as their friends [...]. Neighborhood associations attend the Council meetings, and there they can figure out who is on good terms with him and who is not"(Ambivalent RN Council Member 1, Las Condes). Similarly, another council member explained how, due to their isolation, "there is not much space for rebelliousness [...]. The weight of the mayor is large enough for whoever disagrees with him to feel it. So, [...] there is not much dissidence" (Ambivalent RN Council Member 2, Las Condes). Finally, highlighting the electoral influence of the mayor on local communities, one loyal council member explained that, according to her, "[in the previous election] it was important for the UDI council members to identify with [the mayor]-who is from the UDI too [...]. And people always say: one of the reasons they vote for you is because they 
associate you with the mayor" (Loyal UDI Council Member 2, Las Condes).

\section{The Brokers of the Executive}

As the cases of Estación Central and Quinta Normal illustrate, municipal bureaucracies lacking Las Condes' usability and capacity to address local communities' demands are not necessarily outside the sphere of influence on the local councils' disposition for horizontal accountability. As Table 7 shows, during the period analyzed, the average annual income of these municipalities was below average among Santiago's municipalities, as also were the levels of professionalization of their mid-sized bureaucracies and the resources they dedicated to financial community organizations. As a result, these municipalities' bureaucracies followed more a patrimonial than a bureaucratic pattern and were consistently perceived as incapable and inefficient, while their loyalty to the mayor depended on patronage. Thus, the interviews frequently described these bureaucrats as not having "any preparation to be in their positions," that they got hired only "because of political favors," and as people who "wouldn't have a chance to work at any other place” (Bureaucrat 4, Quinta Normal).

Local communities in these comunas had stronger incentives to turn to council members for help in addressing their demands, and they reward that help with electoral support. Consistently, council members reported that a significant part of their daily activities was dedicated to receiving and addressing these demands, including "domestic problems-that they got bitten by a dog, [that they can't pay] the water or the electricity bills" (Loyal PDC Council Member 1, Quinta Normal). Thus, council members in these municipalities were generally perceived as "just handlers of favors [to local communities]" but that "if [these municipalities] worked properly, [...] delivering goods and services to those who are entitled to them, there would be no need for this type of role" (Skeptic PS Council Member, Estación Central). 
The local executives' influence here stemmed from council members' organizational deficiencies (lack of time and resources), which kept them from receiving and responding to local communities' demands. Specifically, local executives were able to provide council members with a capacity for intercession between local communities and municipal bureaucrats, thus compensating for the organizational deficiencies of both local executives and council members. This ability to intercede consisted of access to three types of resources. First, access to municipal bureaucrats to channel the local demands that council members received. Thus, by granting them "a direct relationship with [the bureaucrats] who manage the processes that neighbors need" they could, for example, "skip all the protocols, speak directly with the head of the department, [and] in fifteen minutes, solve a problem that [a neighbor]had experienced for months" (Collaborator Loyal PDC Council Member 1, Quinta Normal). Second, local executives can provide council members with opportunities to interact with local communities. These instances include, for example, events with local communities, where council members were invited and allowed to "interact with the neighbors" (Loyal UDI Council Member 2, Estación Central), "hand out [gifts], share time with people, [and hear those] who come with a request" (Skeptic PS Council Member, Quinta Normal), and "do their partisan politics [...], and political proselytism" (Bureaucrat 2, Quinta Normal). Finally, mayors can hire more or less personal collaborators to help council members with their duties, including the receiving and processing of local demands.

Consistent with the patrimonial character of these municipal administrations, these opportunities for intercession were granted discretionally to council members, rewarding loyalty and punishing disloyalty to the mayor. As council members described, their capacity to channel local demands to municipal bureaucrats depended "on the willingness of the heads of municipal departments to receive [their] requests," and they were willing only when council members had " $a$ good relationship with the mayor [...]. If you are not on good terms with the mayor, you can forget 
that [your] requests will have any type of support" (Skeptic PS Council Member, Estación Central). Similarly, bureaucrats excluded from activities with local communities those council members who "think that we do everything wrong, [so that], if they need to approve the budget for something, they vote against it because of 'a, ' $b$ ' or 'c' reasons" (Bureaucrat 2, Quinta Normal). Accounting for how loyalty affects the size of a council members' staff, local actors explained that council members loyal to the mayor had more collaborators hired for them (Collaborator Ambivalent UDI Council Member, Estación Central), and that these collaborators were either fired or threatened to be fired when council members failed to support the mayor (Skeptic PS Council Member, Estación Central).

These council members, then, had strong incentives to give up their horizontal accountability duties in exchange for higher chances of increasing their constituent support. As a loyal council member from an opposition party illustrated, he was "loyal to the mayor" and a "bad supervisor" of the local executive because council members "don't have much power-we can listen to neighbors' demands but, in the end, we need to turn to [the mayor] to get their problems solved" (Loyal UDI Council Member 1, Quinta Normal).

\section{Unusable Bureaucracies and Independent Council Members}

As the case of Providencia shows, mayors can lose their influence over council members when they are both ineffective in addressing communities' demands and do not offer opportunities for council members' intercession. For Providencia, the weak loyalty of the municipal bureaucracy—and its consequent low usability—was a critical factor that neutralized the impact of its abundant availability of resources, large and professionalized bureaucracy, and sustained economic and organizational effort to reverse a previous history of low involvement in local communities $^{20}$ (See Tables 7 to 10). According to the interviews, this weak loyalty stemmed from

\footnotetext{
${ }^{20}$ As one municipal bureaucrat explained, when the current mayor assumed command of the municipality
} 
the decision to keep bureaucrats hired by previous administrations to "avoid producing too much noise by changing the municipal team too much" (Bureaucrat 2, Providencia). This decision resulted in a stark division between the old and the new bureaucrats where "the old bureaucrats [were] always waiting [...] for the new ones to leave" (Bureaucrat 1, Providencia), and engaged in active obstruction of the work of the new bureaucrats and the goals of the mayor. Providing an example, the bureaucrats mentioned that "if a memo has to be done within five days, sometimes it takes fifteen, or twenty or twenty-five days. They reject it, [...] try to trap [other bureaucrats] in red tape, [and] deny providing information" (Bureaucrat 1, Providencia). Moreover, although there were "serious problems of management and conflict resolution, [the disloyal bureaucrats did] not work as swiftly, as promptly, or as diligently as was required [to solve these issues]" (Bureaucrat 2, Providencia).

Nor did Providencia develop mechanisms for council members' intermediation as happened in Estación Central and Quinta Normal. Municipal bureaucrats reported that the demands from the community they received through council members were "very few, [...] less than ten in the last year" (Bureaucrat 2, Providencia), while council members admitted "only pass[ing] the information" to the mayor whenever they received a request, thus, refusing to "give an answer saying that [they] can or cannot solve something" and disappointing the neighbors who "think that, if they have one authority on their side, things are going to move faster" (Loyal PS Council Member, Providencia).

Two factors explained these meager levels of the council members' intercession. First, similar to Las Condes, Providencia implemented municipal rules establishing that "all the communications [between bureaucrats and] council members had to be mediated by the [mayor's] cabinet" (Bureaucrat 2, Providencia). Consequently, the relationship between council members and municipal bureaucrats tended to be distant, highly formal and mediated, making the opportunities

\footnotetext{
"there was no associativity, there wasn't practically any local organization. There were six neighborhood associations, which received no more than 230,00o pesos every year. Today we have sixteen neighborhood associations, which receive four million pesos [yearly]" (Bureaucrat 1, Providencia).
} 
for council members' intermediation rare. Second, council members had a "scarce presence in the territory or municipal activities" (Bureaucrat 2, Providencia). As one of them admitted, "council members in [wealthy] communes like Providencia don't have very deep roots with specific groups of voters [because of] the time we have available for our duties. [Here], no one lives only on their council member salary [...]. So, we have less time to get involved” (Loyal PDC Council Member, Providencia).

Under these circumstances, the mayor of Providencia lacked the mechanisms used in the previous cases to compel the council members' loyalty-the high capacity to receive and address community demands that increases the popularity and the electoral influence of the mayor, and the council members' intermediation between local communities and the municipal bureaucracy. Therefore, council members could hold the local administration accountable without risking an electoral sanction from the mayor.

\section{Conclusions}

This paper contrasts with the literature suggesting a positive relationship between state capacity and democracy. As the cases analyzed show, a well-funded, professionalized, and usable bureaucracy, which is highly capable of implementing decisions and providing solutions, can help to obstruct a critical component for liberal democracy: horizontal accountability. Especially when the performance of accountability agents depends on the electoral support they receive, highly capable bureaucracies may discourage these agents from holding the executive accountable by isolating them from their constituents and making their electoral chances dependent on the support of the same executive.

The usability of the bureaucracy, understood as bureaucrats' willingness to cooperate with the current government, plays a critical role in these regards. As the cases analyzed suggest, even when the bureaucracies are highly professionalized and well-funded, the lack of usability reduces the 
public administration's ability to provide public goods and services. In these situations, the executive loses its influence on the electoral chances of accountability agents and, therefore, its capacity to discourage them from holding the executive accountable. However, lower state capacity does not automatically imply a higher disposition for horizontal accountability. If bureaucracies remain usable, the executive can maintain its influence on accountability agents by involving them in the processes of addressing communities' demands. In these cases, accountability agents exchange their willingness to hold the executive accountable for access to resources they can use to distribute among their electorates and, therefore, increase their electoral performance.

These results have important consequences for horizontal accountability as a critical determinant of the quality of democracy. To effectively reduce the corruption and arbitrary use of power that characterize illiberal and delegative democracies, agents of horizontal accountability must be effectively shielded against the influence of the executive, especially when these agents depend on obtaining electoral support. If the executive has access to accountability agents' electorate, and these agents lack the means to secure their electoral support, high bureaucratic capacity can result in an organizational advantage that renders these agents dependent on the executive to obtain the electoral support they need. 


\section{Tables}

Table 1: Characterization of Cases

\begin{tabular}{|c|c|c|c|c|c|c|c|}
\hline \multirow[b]{2}{*}{ Cases } & \multirow{2}{*}{$\begin{array}{c}\text { Socio- } \\
\text { Economic } \\
\text { Status }\end{array}$} & \multirow{2}{*}{$\begin{array}{c}\text { Party } \\
\text { competition }\end{array}$} & \multicolumn{3}{|c|}{ Council Members per Coalition } & \multirow[b]{2}{*}{ Dominant Coalition } & \multirow{2}{*}{$\begin{array}{c}\text { Party of the } \\
\text { Mayor }\end{array}$} \\
\hline & & & $\begin{array}{c}\text { Nueva } \\
\text { Mayoría }\end{array}$ & Alianaza & Total & & \\
\hline Estación Central & Mid-Low & Mid-High & 5 & 3 & 8 & Alianza & UDI \\
\hline Quinta Normal & Mid-Low & Mid-High & 5 & 3 & 8 & Nueva Mayoría & Christian Democrat \\
\hline Providencia & High & High & 4 & 4 & 8 & Nueva Mayoría & Independent (left) \\
\hline Las Condes & High & Low & 1 & 8 & 9 & Alianza & UDI \\
\hline
\end{tabular}

Alianza was a center-right coalition, comprising Unión Demócrata Independiente (UDI) and Renovación Nacional (RN) parties. Nueva Mayoría was a center-left coalition, made of the Christian Democratic (DC), the Socialist (PS), the Radical (PR), the Partido por la Democracia (PPD), and the Communist (PC) parties.

Table 2: Interviews in each Municipality

\begin{tabular}{lccccc}
\hline \hline Cases & $\begin{array}{c}\text { Parliament } \\
\text { Representatives }\end{array}$ & $\begin{array}{c}\text { Council } \\
\text { Members }\end{array}$ & $\begin{array}{c}\text { Municipal } \\
\text { Bureaucrats }\end{array}$ & $\begin{array}{c}\text { Local } \\
\text { Leaders }\end{array}$ & Total \\
\hline Estación Central & $\mathbf{1}$ & 6 & 6 & 5 & $\mathbf{1 8}$ \\
Quinta Normal & $\mathbf{2}$ & 5 & 7 & 7 & $\mathbf{2 1}$ \\
Providencia & $\mathbf{1}$ & 4 & 3 & 5 & $\mathbf{1 3}$ \\
Las Condes & $\mathbf{1}$ & 5 & 3 & 5 & $\mathbf{1 4}$ \\
\hline Total & $\mathbf{6}$ & $\mathbf{2 3}$ & $\mathbf{2 2}$ & $\mathbf{2 7}$ & $\mathbf{7 8}$ \\
\hline \hline
\end{tabular}

Table 3: Secondary Sources of Information for the Dependent Variable*

\begin{tabular}{lccc|c}
\hline \hline Cases & $\begin{array}{c}\text { Reports in } \\
\text { Printed News }\end{array}$ & $\begin{array}{c}\text { Reports in } \\
\text { Electronic News }\end{array}$ & $\begin{array}{c}\text { Total News } \\
\text { Reports }\end{array}$ & $\begin{array}{c}\text { Reports to } \\
\text { CGO }\end{array}$ \\
\hline Estación Central & 5 & 21 & 26 & $\mathbf{2}$ \\
Quinta Normal & 4 & 1 & 5 & $\mathbf{8}$ \\
Providencia & 26 & 16 & $\mathbf{4 2}$ & 5 \\
Las Condes & 8 & 7 & $\mathbf{1 5}$ & $\mathbf{0}$ \\
Total & 43 & $\mathbf{9 7}$ & $\mathbf{1 4 0}$ & $\mathbf{1 7}$ \\
\hline
\end{tabular}

*News reports in national printed and electronic news sources were considered for Estación Central, Quinta Normal, Providencia, and Las Condes. 
Table 4: Independent Variables

\begin{tabular}{|c|c|c|}
\hline Relationshps & Dimensions & Sources (type of information) \\
\hline \multirow{3}{*}{$\begin{array}{l}\text { Council Members- } \\
\text { Local Communities }\end{array}$} & $\begin{array}{l}\text { History of Involvement } \\
\text { in Local Communities }\end{array}$ & Interviews (general) \\
\hline & $\begin{array}{l}\text { Current Interactions with } \\
\text { Local Communities }\end{array}$ & Interviews (general) \\
\hline & $\begin{array}{l}\text { involvement in local } \\
\text { problem-solving }\end{array}$ & Interviews (general) \\
\hline \multirow[t]{2}{*}{$\begin{array}{l}\text { Council Members- } \\
\text { Local Excecutives }\end{array}$} & $\begin{array}{l}\text { Council Members' } \\
\text { Intermediation }\end{array}$ & Interviews (general) \\
\hline & $\begin{array}{l}\text { Availability of Financial } \\
\text { Resources }\end{array}$ & $\begin{array}{l}\text { Interviews (general) } \\
\text { SINIM (municipalities' incomes) }\end{array}$ \\
\hline \multirow{4}{*}{$\begin{array}{l}\text { Local Excecutives- } \\
\text { Local Communities }\end{array}$} & $\begin{array}{l}\text { Active Involvement With } \\
\text { Local Communities }\end{array}$ & $\begin{array}{l}\text { Interviews (general) } \\
\text { SINIM; Chile's Ministry of } \\
\text { Finance (funds transfers to local } \\
\text { organizations) }\end{array}$ \\
\hline & & $\begin{array}{l}\text { CASEN } 2015 \text { Survey (participation } \\
\text { in local organizations) }\end{array}$ \\
\hline & & Interviews (general) \\
\hline & $\begin{array}{l}\text { Capacity to Receive and } \\
\text { Respond to Local } \\
\text { Demands }\end{array}$ & $\begin{array}{l}\text { SINIM (size and } \\
\text { provesionallization of } \\
\text { bureaucracies) }\end{array}$ \\
\hline
\end{tabular}

Table 5: Municipal Council's Disposition for Horizontal Accountability

\begin{tabular}{|c|c|c|c|c|c|c|c|c|c|c|c|c|}
\hline \multirow{3}{*}{ Cases } & \multicolumn{12}{|c|}{ Council Members' Disposition for Horizontal Accountability } \\
\hline & \multicolumn{4}{|c|}{ Mayors' Coalition } & \multicolumn{4}{|c|}{ Opposition Parties } & \multicolumn{3}{|c|}{ Total } & \multirow{2}{*}{$\begin{array}{c}\text { Councils' } \\
\text { Disposition }\end{array}$} \\
\hline & Loyal & Ambivalent & Skeptical & Total & Loyal & Ambivalent & Skeptical & Total & Loyal & Ambivalent & Skeptical & \\
\hline Las Condes & 6 & 2 & o & 8 & o & o & 1 & $\mathbf{1}$ & 6 & 2 & $\mathbf{1}$ & Low \\
\hline Estación Central & 2 & 1 & o & 3 & 1 & 2 & 2 & 5 & 3 & 3 & 2 & Medium \\
\hline Quinta Normal & 3 & o & 2 & 5 & 2 & o & 1 & 3 & 5 & $\mathbf{o}$ & 3 & Medium \\
\hline Providencia & 3 & $\mathrm{o}$ & 1 & 4 & o & $\mathrm{o}$ & 4 & 4 & 3 & $\mathbf{o}$ & 5 & High \\
\hline
\end{tabular}


Table 6: Possible Explanations for Municipal Council's Disposition for Horizontal Accountability

\begin{tabular}{|c|c|c|c|c|c|c|c|}
\hline Cases & $\begin{array}{c}\text { Commune's } \\
\text { SES }\end{array}$ & $\begin{array}{c}\text { Party } \\
\text { Competition }\end{array}$ & $\begin{array}{l}\text { Mayors' } \\
\text { Coalition }\end{array}$ & $\begin{array}{c}\text { Bureaucratic } \\
\text { capacity to address } \\
\text { demands }\end{array}$ & $\begin{array}{c}\text { Council } \\
\text { members' } \\
\text { intermediation }\end{array}$ & $\begin{array}{l}\text { Council members' } \\
\text { independent } \\
\text { constituent support }\end{array}$ & $\begin{array}{c}\text { Councils' } \\
\text { Disposition }\end{array}$ \\
\hline Las Condes & High & Low & Center-Right & High & Low & Low & Low \\
\hline Estación Central & Mid-Low & Mid-High & Center-Right & Low & Mid-High & Mid-Low & Medium \\
\hline Quinta Normal & Mid-Low & Mid-High & Center-Left & Low & Mid-High & Mid-Low & Medium \\
\hline
\end{tabular}

Table 7: Municipal Own Income 2013-2016

(Total and Per Capita annual averages. Amounts in thousands of pesos)

\begin{tabular}{lccccc}
\hline \hline & \multicolumn{2}{c}{ Total } & & \multicolumn{2}{c}{ Per Capita } \\
\cline { 2 - 3 } \cline { 5 - 6 } Municipality & $\begin{array}{c}\text { Annual } \\
\text { Average }\end{array}$ & $\begin{array}{c}\text { Rank }^{*} \\
(\text { of 34) }\end{array}$ & & $\begin{array}{c}\text { Annual } \\
\text { Average }\end{array}$ & $\begin{array}{c}\text { Rank }^{*} \\
\text { (of 34) }\end{array}$ \\
\hline Las Condes & $110,051,792$ & $\mathbf{1}$ & & 386 & 4 \\
Providencia & $56,457,004$ & 5 & & 396 & 3 \\
Estación Central & $17,481,034$ & 17 & & 129 & 11 \\
Quinta Normal & $9,564,115$ & 29 & & 90 & 27 \\
\hline Average* $^{26,415,553}$ & & & 152 & \\
\hline
\end{tabular}

*Rank and Average considering all the municipalities in Santiago.

Source: Created by the author based on information from Sistema Nacional de Información Municipal (SINIM), available online at http://www.sinim.gov.cl. Data on municipal population obtained from Chile's National Statistics Institute (INE. Estimations based on 2002 national census --Reported by the National System of Municipal Information (SINIM. Available online at http://www.sinim.gov.cl).

Table 8: Municipal Transferences of Public Funds to Private Organizations 2013-2016 (Total and Per Capita annual averages. Amounts in thousands of pesos)

\begin{tabular}{lccccc}
\hline \hline Municipality & \multicolumn{2}{c}{ Total } & & \multicolumn{2}{c}{ Per Capita } \\
\cline { 2 - 3 } \cline { 5 - 6 } & Annual Average & $\begin{array}{c}\text { Rank }^{*} \\
\text { (of 34) }\end{array}$ & & Annual Average & $\begin{array}{c}\text { Rank }^{*} \\
\text { (of 34) }\end{array}$ \\
\hline Las Condes & $36,563,075$ & 1 & & 128 & 1 \\
Providencia & $8,673,626$ & 5 & & 61 & 3 \\
Estación Central & 453 & 20 & & 3 & 18 \\
Quinta Normal & 63 & 27 & & 0.005 & 26 \\
\hline Average $^{*}$ & $4,402,295$ & & 41 & \\
\hline
\end{tabular}

*Rank and Average considering all the municipalities in Santiago.

Source: created by the author based on data on municipalities' transferences of public funds to private organizations, obtained from Registro Central de Colaboradores del Estado of Chile's Ministry of Finance (Ministerio de Hacienda), according to the law № 19862 (available online at https://www.registros19862.cl). Municipalities' average obtained considering only the years for which the reported data on this item. Data on municipal population obtained from Chile's National Statistics Institute (INE. Estimations based on 2002 national census --Reported by the National System of Municipal Information (SINIM. Available online at http://www.sinim.gov.cl). 
Table 91: Size of Municipal Bureaucracies 2013-2016

(Total and Per Capita annual averages)

\begin{tabular}{|c|c|c|c|c|c|}
\hline \multirow[b]{2}{*}{ Municipality } & \multicolumn{3}{|c|}{ Total } & \multicolumn{2}{|c|}{ Per Capita } \\
\hline & $\begin{array}{l}\text { Annual } \\
\text { Average }\end{array}$ & $\begin{array}{l}\text { Rank* } \\
(\text { of } 34)\end{array}$ & $\begin{array}{l}\text { Size } \\
\text { group }\end{array}$ & $\begin{array}{l}\text { Annual } \\
\text { Average }\end{array}$ & $\begin{array}{l}\text { Rank }^{*} \\
(\text { of 34) }\end{array}$ \\
\hline Providencia & 907 & 2 & Large & 6.4 & 2 \\
\hline Las Condes & 753 & 3 & Large & 3.5 & 17 \\
\hline Estación Central & 462 & 6 & Mid-Large & 3.1 & 5 \\
\hline Quinta Normal & 320 & 16 & Medium & 2.6 & 9 \\
\hline Average* $^{*}$ & $55^{2}$ & & & $3 \cdot 4$ & \\
\hline
\end{tabular}

${ }^{*}$ Rank and Average considering all the municipalities in Santiago.

Source: Created by the author based on information from Sistema Nacional de Información Municipal (SINIM), available online at http://www.sinim.gov.cl. Numbers consider only bureaucrats that were either part of the civil service system (planta) or working under fixed-term contracts (contrata), thus excluding bureaucrats working under fee-for-service contracts (honorarios). Data on municipal population obtained from Chile's National Statistics Institute (INE. Estimations based on 2002 national census --Reported by the National System of Municipal Information (SINIM. Available online at http://www.sinim.gov.cl).

Table 102: Proportion of Professional in Municipal Bureaucracies 2013-2016

\begin{tabular}{lclcc}
\hline \hline Municipality & $\begin{array}{c}\text { Average \% of } \\
\text { professionals }\end{array}$ & Size Group* & $\begin{array}{c}\text { Municipalities } \\
\text { in Size Group* }\end{array}$ & $\begin{array}{c}\text { Rank* }^{*} \\
\text { (in size group) }\end{array}$ \\
\hline Providencia & $\mathbf{3 2 \%}$ & Large $(500+)$ & 5 & $\mathbf{1}$ \\
Las Condes & $\mathbf{2 7 \%}$ & Large (500 +) & 5 & $\mathbf{2}$ \\
\hline Estación Central & $\mathbf{1 8 \%}$ & Mid-Large (350-499) & 6 & 6 \\
\hline Quinta Normal & $\mathbf{1 7 \%}$ & Medium (290-349) & $\mathbf{1 4}$ & $\mathbf{1 3}$ \\
\hline
\end{tabular}

${ }^{*}$ Rank and Size groups considering all the municipalities in Santiago.

Source: Created by the author based on information from Sistema Nacional de Información Municipal (SINIM), available online at http://www.sinim.gov.cl. Level of Professionalization considers only bureaucrats that were either part of the civil service system (planta) or working under fixed-term contracts (contrata), thus excluding bureaucrats working under fee-for-service contracts (honorarios). The categories of the size of municipal administrations were created by the author considering the breaks in the distribution of the data and based on the data obtained from Sistema Nacional de Información Municipal (SINIM available online at http://www.sinim.gov.cl) 


\section{Works Cited}

Agrawal, Arun, and Krishna Gupta. 2005. "Decentralization and Participation: The Governance of Common Pool Resources in Nepal's Terai." World Development 33 (7): 1101-14. https://doi.org/10.1016/j.worlddev.2005.04.009.

Ahmad, Junaid Kamal, Shantayanan Devarajan, Stuti Khemani, and Shekhar Shah. 2005. "Decentralization and Service Delivery." SSRN Scholarly Paper ID 753505. Rochester, NY: Social Science Research Network. https://papers.ssrn.com/abstract=753505.

Albertus, Michael, and Victor Menaldo. 2012. "Coercive Capacity and the Prospects for Democratization." Comparative Politics 44 (2): 151-69. https://doi.org/10.5129/001041512798838003.

Bäck, Hanna, and Axel Hadenius. 2008. "Democracy and State Capacity: Exploring a J-Shaped Relationship." Governance 21 (1): 1-24. https://doi.org/10.1111/j.1468-0491.2007.00383.x.

Bardhan, Pranab, and Dilip Mookherjee. 2000. "Capture and Governance at Local and National Levels." American Economic Review 90 (2): 135-39. https://doi.org/10.1257/aer.90.2.135.

Behrend, Jacqueline. 2011. "The Unevenness of Democracy at the Subnational Level: Provincial Closed Games in Argentina." Latin American Research Review 46 (1): 150-76. https://doi.org/10.1353/lar.2011.0013.

Behrend, Jacqueline, and Laurence Whitehead, eds. 2016. Illiberal Practices: Territorial Variance within Large Federal Democracies. Baltimore: Johns Hopkins University Press.

Bellin, Eva. 2004. "The Robustness of Authoritarianism in the Middle East: Exceptionalism in Comparative Perspective." Comparative Politics 36 (2): 139. https://doi.org/10.2307/4150140.

Bendix, Reinhard. 1998. Max Weber: An Intellectual Portrait. Max Weber Classic Monographs, v. 2. London ; New York: Routledge.

Blair, Harry. 2000. "Participation and Accountability at the Periphery: Democratic Local Governance in Six Countries." World Development 28 (1): 21-39. https://doi.org/10.1016/S0305-750X(99)00109-6.

Bland, Gary. 2011. "Considering Local Democratic Transition in Latin America." Journal of Politics in Latin America 3 (1): 65-98.

Bowman, Ann, and Richard Kearney. 2011. State and Local Government. Eighth edition. Boston, MA: Wadsworth Cengage Learning.

Bunce, Valerie. 2000. "Comparative Democratization: Big and Bounded Generalizations." Comparative Political Studies 33 (6-7): 703-34. https://doi.org/10.1177/001041400003300602.

Calvo, Ernesto, and Maria Victoria Murillo. 2004. "Who Delivers? Partisan Clients in the Argentine Electoral Market." American Journal of Political Science 48 (4): 742-57. https://doi.org/10.1111/j.00925853.2004.00099.x.

Cornelius, Wayne A., Todd A. Eisenstadt, and Jane Hindley, eds. 1999. Subnational Politics and Democratization in Mexico. U.S.-Mexico Contemporary Perspectives Series 13. La Jolla: Center for U.S.-Mexican Studies, University of California, San Diego.

Crook, Richard. 1999. "'No-party' Politics and Local Democracy in Africa: Rawlings' Ghana in the 1990s and the "Ugandan Model.'” Democratization 6 (4): 114-38. https://doi.org/10.1080/13510349908403635.

Delamaza, Gonzalo. 2018. “Introducción.” In Juntas de Vecinos En Chile : 50 Años, Historia y Desafíos de Participación, edited by Gonzalo Delamaza and María Teresa Corvera, Ediciones Biblioteca del Congreso Nacional de Chile. Santiago de Chile.

Devas, Nick, and Simon Delay. 2006. "Local Democracy and the Challenges of Decentralising the State: An International Perspective." Local Government Studies 32 (5): 677-95. https://doi.org/10.1080/03003930600896293.

Diamond, Larry, and Leonardo Morlino. 2004. "The Quality of Democracy: An Overview." Journal of Democracy 15 (4): 20-31. https://doi.org/10.1353/jod.2004.0060.

Dixit, Avinash, and John Londregan. 1996. "The Determinants of Success of Special Interests in Redistributive Politics." The Journal of Politics 58 (04): 1132-1155. https://doi.org/10.2307/2960152.

Ducci, María Elena. 2002. "Área Urbana de Santiago 1991-2000: Expansión de La Industria y La Vivienda." EURE (Santiago) 28 (85). https://doi.org/10.4067/S0250-71612002008500010.

Fernández Richard, José. 2013. "La Administración Del Estado y Las Municipalidades En Chile." Revista IUS 7 (32): $148-60$. 
Fortin, Jessica. 2012. "Is There a Necessary Condition for Democracy? The Role of State Capacity in Postcommunist Countries." Comparative Political Studies 45 (7): 903-30. https://doi.org/10.1177/0010414011428587.

Fortin-Rittberger, Jessica. 2014. "The Role of Infrastructural and Coercive State Capacity in Explaining Different Types of Electoral Fraud." Democratization 21 (1): 95-117. https://doi.org/10.1080/13510347.2012.724064.

Fukuyama, Francis. 2004. State-Building: Governance and World Order in the 21st Century. Ithaca, N.Y: Cornell University Press.

Gervasoni, Carlos. 2010. "Measuring Variance in Subnational Regimes: Results from an Expert-Based Operationalization of Democracy in the Argentine Provinces." Journal of Politics in Latin America 2 (2): 1352. https://doi.org/10.1177/1866802X1000200202.

Gibson, Edward L. 2005. "Boundary Control: Subnational Authoritarianism in Democratic Countries." World Politics 58 (1): 101-32. https://doi.org/10.1353/wp.2006.0018.

Giraudy, Agustina. 2013. "Varieties of Subnational Undemocratic Regimes: Evidence from Argentina and Mexico." Studies in Comparative International Development 48 (1): 51-80. https://doi.org/10.1007/s12116-0129117-4.

Grzymała-Busse, Anna Maria. 2007. Rebuilding Leviathan: Party Competition and State Exploitation in PostCommunist Democracies. Cambridge Studies in Comparative Politics. Cambridge ; New York: Cambridge University Press.

Hashim, S. Mohsin. 2005. "Putin's Etatization Project and Limits to Democratic Reforms in Russia放." Communist and Post-Communist Studies 38 (1): 25-48. https://doi.org/10.1016/j.postcomstud.2005.01.005.

Herrmann, Julián Durazo. 2010. "Neo-Patrimonialism and Subnational Authoritarianism in Mexico. The Case of Oaxaca." Journal of Politics in Latin America 2 (2): 85-112. https://doi.org/10.1177/1866802X1000200204.

Hiskey, Jonathan, and Mitchell Seligson. 2003. "Pitfalls of Power to the People: Decentralization, Local Government Performance, and System Support in Bolivia." Studies in Comparative International Development 37 (4): 64-88. https://doi.org/10.1007/BF02686272.

Huber, Evelyne, Dietrich Rueschemeyer, and John D. Stephens. 1997. "The Paradoxes of Contemporary Democracy: Formal, Participatory, and Social Dimensions." Comparative Politics 29 (3): 323. https://doi.org/10.2307/422124.

Kaufman, Robert R., Sylvia Maxfield, Barbara Geddes, and Robert D. Putnam. 1999. "Approaches to the Study of State Reform in Latin American and Postsocialist Countries." Comparative Politics 31 (3): 357. https://doi.org/10.2307/422344.

Keefer, Philip, and David Stasavage. 1999. Checks and Balances, Private Information, and the Credibility of Monetary Commitments. Policy Research Working Papers. The World Bank. https://doi.org/10.1596/1813-9450-2542.

Kitschelt, Herbert, and Steven I. Wilkinson. 2007. Patrons, Clients and Policies: Patterns of Democratic Accountability and Political Competition. Cambridge University Press.

Kochanowicz, Jacek. 1994. "Reforming Weak States and Deficient Bureaucracies." In Intricate Links: Democratization and Market Reforms in Latin America and Eastern Europe, edited by Joan M. Nelson. U.S.-Third World Policy Perspectives, no. 20. New Brunswick, N.J., USA: Transaction Publishers.

Lankina, Tomila. 2008. "Cross-Cutting Literature Review on the Drivers of Local Council Accountability and Performance." Social Development Working Paper 112. Local Governance \& Accountabiity. Washington, DC: World Bank.

Lawson, Andrew, and Lise Rakner. 2005. "Final Synthesis Report." Working Paper. Understanding Patterns of Accountability in Tanzania. Oxford: Oxford Policy Management; Chr. Michelsen Institute; Research on Poverty Alleviation.

Levitsky, Steven, and Lucan Way. 2010. Competitive Authoritarianism: Hybrid Regimes after the Cold War. Problems of International Politics. New York: Cambridge University Press.

Ley No 18.695, Orgánica Constitucional de Municipalidades. 2006. https://www.leychile.cl/Navegar?idNorma=251693.

Ley $N^{\circ}$ 19.418, Sobre Juntas de Vecinos Demás Organizaciones Comunitarias. 1997. https://www.leychile.cl/Navegar?idNorma=70040\&buscar=Juntas+de+Vecinos. 
Linz, Juan J., and Alfred C. Stepan. 1996. Problems of Democratic Transition and Consolidation: Southern Europe, South America, and Post-Communist Europe. Baltimore: Johns Hopkins University Press.

Luna, Juan Pablo. 2016. “Chile's Crisis of Representation." Journal of Democracy 27 (3): 129-38. https://doi.org/10.1353/jod.2016.0046.

Luna, Juan Pablo, and David Altman. 2011. "Uprooted but Stable: Chilean Parties and the Concept of Party System Institutionalization." Latin American Politics and Society 53 (02): 1-28. https://doi.org/10.1111/j.15482456.2011.00115.x.

Mainwaring, Scott. 2003. "Introduction: Democratic Accountability in Latin America." In Democratic Accountability in Latin America, 3-33. OUP Oxford.

Mainwaring, Scott, and Christopher Welna, eds. 2003. Democratic Accountability in Latin America. Oxford Studies in Democratization. Oxford ; New York: Oxford University Press.

Mann, Michael. 1984. "The Autonomous Power of the State: Its Origins, Mechanisms and Results." European Journal of Sociology / Archives Européennes de Sociologie 25 (02): 185-213. https://doi.org/10.1017/S0003975600004239.

Marshall, Monty, and Ted Gurr. 2014. "Polity IV Project: Political Regime Characteristics and Transitions, 18002013." Center of Systemic Peace. 2014. http://www.systemicpeace.org/polity/polity4x.htm.

Mazzuca, Sebastián. 2012. "O'Donnell and the Study of Latin American Politics After the Transitions." STUDIA POLITICAE, 27.

Mazzuca, Sebastián L., and Gerardo L. Munck. 2014. "State or Democracy First? Alternative Perspectives on the State-Democracy Nexus." Democratization 21 (7): 1221-43. https://doi.org/10.1080/13510347.2014.960209.

Montero, Alfred P., David Samuels, and Helen Kellogg Institute for International Studies, eds. 2004. Decentralization and Democracy in Latin America. Notre Dame, Ind: University of Notre Dame Press.

Moreno, Erika, Brian Crisp, and Matthew Shugart. 2003. "The Accountability Deficit in Latin America." In Democratic Accountability in Latin America, edited by Scott Mainwaring and Christopher Welna, 79-131. Oxford Studies in Democratization. Oxford ; New York: Oxford University Press.

Mulgan, Richard. 2000. “'Accountability': An Ever-Expanding Concept?” Public Administration 78 (3): 555-73. https://doi.org/10.1111/1467-9299.00218.

Nickson, Andrew. 2011. "Where Is Local Government Going in Latin America? A Comparative Perspective." Working Paper 6. Visby, Sweden: Swedish International Centre for Local Democracy.

O’Donell, Guillermo. 1994. “Delegative Democracy." Journal of Democracy 5 (1): 55-69. https://doi.org/10.1353/jod.1994.0010.

O'Donnell, Guillermo A. 2003. "Horizontal Accountability: The Legal Institutionalization of Mistrust." In Democratic Accountability in Latin America, edited by Scott Mainwaring and Christopher Welna, 34-54. Oxford Studies in Democratization. Oxford ; New York: Oxford University Press.

OECD. 2017. Making Decentralisation Work in Chile: Towards Stronger Municipalities. OECD Multi-Level Governance Studies. OECD. https://doi.org/10.1787/9789264279049-en.

Packel, Daniel. 2008. "Electoral Institutions and Local Government Accountability: A Literature Review." Social Development Working Paper 111. Local Governance \& Accountabiity. Washington, DC: World Bank.

Pino, Juan Federico. 2017. "Entre Democracias y Autoritarismos: Una Mirada Crítica al Estudio de La Democracia Subnacional En Colombia y Latinoamérica." Colombia Internacional 91 (July): 215-42. https://doi.org/10.7440/colombiaint91.2017.07.

Przeworski, Adam, ed. 1995. Sustainable Democracy. Cambridge, [England] ; New York: Cambridge University Press.

Read, Benjamin Lelan. 2012. Roots of the State: Neighborhood Organization and Social Networks in Beijing and Taipei. Contemporary Issues in Asia and the Pacific. Stanford, California: Stanford University Press.

Rivera-Ottenberg, Anny. 2004. "The Pobladores and Local Democracy in Chile: The Cases of El Bosque and Peñalolen." Ph.D. diss., Boston: Massachusetts Institute of Technology.

Roberts, Cynthia, Thomas Sherlock, Joseph R. Blasi, Maya Kroumova, Douglas Kruse, M. Steven Fish, Juan Linz, Alfred Stepan, and Michael McFaul. 1999. "Bringing the Russian State Back in: Explanations of the Derailed Transition to Market Democracy." Comparative Politics 31 (4): 477. https://doi.org/10.2307/422241.

Rosales, Mario. 2007. “Chile: Un Municipio Social con Limitaciones para Impulsar el Desarrollo Local." In Procesos 
políticos comparados en los municipios de Argentina y Chile (1990 - 2005), edited by Daniel Cravacuore and Ricardo Israel Zipper, 1. ed, 143-66. Bernal: Univ. Nacional de Quilmes: Universidad Autónoma de Chile.

Sabatini, Francisco, Gonzalo Cáceres, and Jorge Cerda. 2001. "Segregación Residencial En Las Principales Ciudades Chilenas: Tendencias de Las Tres Últimas Décadas y Posibles Cursos de Acción." EURE (Santiago) 27 (82). https://doi.org/10.4067/S0250-71612001008200002.

Saylor, Ryan. 2014. State Building in Boom Times: Commodities and Coalitions in Latin America and Africa. New York, NY: Oxford University Press, USA.

Schaffer, Frederic, and Scott Desposato, eds. 2007. "How Does Vote Buying Shape the Legislative Arena?" In Elections for Sale: The Causes and Consequences of Vote Buying, 123-44. Boulder, Colo: Lynne Rienner Publishers.

Schedler, Andreas, Larry Diamond, and Marc Plattner, eds. 1999. The Self-Restraining State: Power and Accountability in New Democracies. Boulder, Colo.: Lynne Rienner Publ.

Schumpeter, Joseph A. 2008. Capitalism, Socialism, and Democracy. 1st ed. New York: Harper Perennial Modern Thought.

Seawright, Jason, and John Gerring. 2008. "Case Selection Techniques in Case Study Research: A Menu of Qualitative and Quantitative Options." Political Research Quarterly 61 (2): 294-308. https://doi.org/10.1177/1065912907313077.

Sisk, Timothy, ed. 2001. Democracy at the Local Level: The International IDEA Handbook on Participation, Representation, Conflict Management and Governance. International IDEA Handbook Series 4. Stockholm: Internat. IDEA.

Soifer, Hillel. 2008. "State Infrastructural Power: Approaches to Conceptualization and Measurement." Studies in Comparative International Development 43 (3-4): 231-51. https://doi.org/10.1007/s12116-008-9028-6.

Suleiman, Ezra. 1999. "Bureaucracy and Democratic Consolidation: Lessons from Eastern Europe." In Transitions to Democracy, edited by Lisa Anderson, 141-67. New York: Columbia University Press.

The Fund for Peace. 2019. “Fragile States Index Annual Report 2019." Washington, D.C.: The Fund for Peace. https://fragilestatesindex.org/wp-content/uploads/2019/03/9511904-fragilestatesindex.pdf.

Tilly, Charles. 2007. Democracy. Cambridge, [England] ; New York: Cambridge University Press.

Transparency International, ed. 2012. Corruption Perceptions Index 2012. Berlin: Transparency International.

Wang, Xu, Joel S. Migdal, Atul Kohli, Vivienne Shue, and Peter Evans. 1999. "Mutual Empowerment of State and Society: Its Nature, Conditions, Mechanisms, and Limits." Comparative Politics 31 (2): 231. https://doi.org/10.2307/422146.

Way, Lucan A. 2005. "Authoritarian State Building and the Sources of Regime Competitiveness in the Fourth Wave: The Cases of Belarus, Moldova, Russia, and Ukraine." World Politics 57 (2): 231-61. https://doi.org/10.1353/wp.2005.0018.

Weber, Max. 2014. "Bureaucracy." In From Max Weber, edited by H. H. Gerth and C. Wright Mills, 196-244. Hoboken: Taylor and Francis.

http://public.ebookcentral.proquest.com/choice/publicfullrecord.aspx?p=1683550.

Weingast, Barry R., and Mark J. Moran. 1983. "Bureaucratic Discretion or Congressional Control? Regulatory Policymaking by the Federal Trade Commission." Journal of Political Economy 91 (5): 765-800. https://doi.org/10.1086/261181.

Wirls, Daniel. 2015. The Federalist Papers and Institutional Power in American Political Development. http://public.eblib.com/choice/publicfullrecord.aspx?p=2009936_0.

Zakaria, Fareed. 1997. "The Rise of Illiberal Democracy." Foreign Affairs 76: 22. 